might have been anticipated, and I greatly fear that the new and degraded standard will lead to more ill-health, to respiratory disease, and especially to an increase in the number of consumptives.

I am, Sir, yours faithfully,

Bournemouth, Jan. 22nd, 1912. ARTHUR RANSOME.

\section{INTESTINAL MYIASIS.}

\section{To the Editor of THE LANCET.}

SIR,-The addition of a few references to Dr. $\mathbf{E}$. A. Cockayne's bibliography in his interesting paper on Intestinal Myiasis would make it more complete. I have seen five such cases in infants, in four of which the larvæ were present in the stools and in one they were found in the vomit. The particular varieties were not identified.

I am, Sir, yours faithfully,

Park-street, W., Jan. 23rd, 1912. EDMUND CaUTLEY.

Additional bibliography.-1. Cohn: Deutsche Medicinische Wnchenschrift, March 24th, 1898; age 3 months; larvæ in vomit and fæces. 2. Keenan : TH L LANCET, 1903, vol. i.. p. 200 ; infant; larve in vomit. 3. S. M. Lawrence : Brit. Med. Jour., 19i0, vol. i1.. p. 376. 4. A. $\mathbf{E}$ May : Brit. Med.Jour., 1906, vol. ii., p. 180. 5. A. B. Northgate : Brit Med. Jour., 1906, vol, ii, p. 180. 6. J. Smyth: THE LANCET, 19J2 three males, an adult, a boy, and an infant with larvæ in the stools.

To the Editor of THE LANCET.

SIR,-Dr. F. A. Cockayne in his interesting article in THE LANCET of Jan. 20th on "Intestinal Myiasis" says : "There is still a little doubt as to how the larvæ gain access to the intestinal tract," and then mentions various articles of food, among which milk is conspicuous by its absence. I have on several occasions observed that the ovipositor of a fly drowned in milk has been extruded, and I have little doubt that the eggs were in the milk, though I did not search for them. I have recorded observations that when temperature conditions were favourable, fermentation of food stuffs was not an essential factor in the growth of the larvæ of the house fly. In cases of intestinal myiasis the eggs or young larvæ might easily be introduced in milk from which a drowned fly has been removed-a not infrequent incident in many homes in the "fly" months.

Flies will live through the winter in a warm kitchen or bakehouse, and milk is frequently kept in such places. The colour of the milk prevents the ova or larvæ being observed without careful straining and minute examination. Even the extraordinary cases in which larvæ have been passed for months or years may also thus be explained.

Norwich, Jan. 20th, 1912. I am, Sir, yours faithfully, J. T. C. NASH.

\section{SENSORY DISTURBANCES AND CEREBRAL LESIONS.}

To the Editor of THE LANOET.

SrR,-Among the many conclusions arrived at by $\mathrm{Dr}$ Henry Head and Dr. Gordon Holmes in their studies of the sensory distarbances resulting from cerebral lesions, ${ }^{1}$ I find none more interesting than that which assigns to the optic thalamus, or rather the "essential organ" of this structure, a leading rôle in the genesis of feeling (affective) tone. This element of feeling tone not only enters largely into the massive sensations of pleasure and discomfort, but also into emotional feelings, such as fear, joy, anger, gloom; it constitutes, moreover, the essential ingredient of mental temperament and of moods.

The suggestion that feeling tone is largely determined by the activity of a limited portion of brain tissue may to some appear somewhat startling. When, however, we call to mind that a creature with a brain no larger than a pea, such as a mouse or small bird, is capable of as highly developed affective tone as man himself, it becomes evident (1) that a diminutive mass of brain tissue suffices for the genesis of affective tone; and (2) that the enormous development of the cerebral hemispheres in the higher mammals is not for the purpose of adding to feeling capacity in its grosser aspects, but, on the contrary, is essentially bound up with intellectual development-a conclusion, needless to say, in entire

\footnotetext{
I ThE LANCET, Jan. 6th (p. 1), 13th (p. 79), and 20th (p. 144), 1912.
}

harmony with the views of Dr. Head and Dr. Holmes as to the rôle which the cerebral hemispheres play in sensation.

The identification of feeling tone with the optic thalamus helps us to understand the anatomico-physiological mechanism pertaining to moods and mental temperament. If these depend, as they undoubtedly largely do, on feeling tone, and if feeling tone is closely associated with the activity of the optic thalamus, then moods and temperament must be closely dependent upon the activity of this organ. Now feeling tone is profoundly influenced by the state of the blood (witness the change in the affestive nature during the rutting time, and as the result of the action of such substances as alcohol and morphine), and we therefore seem justified in assuming that temperament and moods depend in large measure upon the manner in which that subtly complex and ever-changing fluid, the blood, plays upon a particular part of the mind instrument-to wit, the optic thalamus.

I may here remark parenthetically that there is strong evidence in favour of the conclusion that differences in mental temperament essentially depend, not upon differences in brain organisation, but upon differences in blood composition; not upon differences in the structure of the mind instrument, but upon differences in the way that instrument is played upon by the blood.

May I, Sir, in conclusion suggest that the authors of these remarkable articles might throw still more light on a subject they have done so much to illuminate, by investigating the effects on the various forms of sensibility of substances such as alcohol and morphine?

I am, Sir, yours faithfully,

Wimpole-street, Jan. 20th, 1912. HARRY OAMPBHIL.

\section{NON-TUBERCULOUS MILK IN GUERNSEY. \\ To the Editor of THE LaNCET.}

SIR, - The recent report of the Royal Commission upon Tuberculosis has called attention to the fact that a large proportion of the tuberculosis of children and young people is due to the consumption of milk from cows affected with this disease. Until 1906 tuberculosis was apparently unknown amongst Guernsey cattle, but it was then introduced by cattle re-imported after having been to England for exbibition. This re-importation is now forbidden, and drastic laws have been passed compelling the slaughter of all infected cattle and granting State compensation. As a result the disease has been practically stamped out, and of the 1364 animals exported during the past three years, all of which were tested with tuberculin, only six were found to be affected. This gives tuberculosis a rate of under $\frac{1}{2}$ per cent. compared with the estimate of Sir John McFadyean, principal of the Royal Veterinary College, London, of 20 per cent. of adults cows in England.

The forms of human tuberculosis chiefly caused by bovine tuberculosis (tubercular glands of neck, abdominal tuberculosis, and lupus) are consequently exceedingly rare in the island of Guernsey. Channel Islands' cows give the riehest milk in the world, the average of fat for Guernsey cattle being over 60 per cent. above the Inglish legal standard for fat. It is impossible to over.rate the importance, especially where children and delicate persons are concerned, of milk so rich in butter fat, and above all so free from the germs of the scourge of taberculosis - I am, Sir, yours faithfully,

HENRY DRAPER BISHOP.

Medical Officer of Health, States of Guernsey.

Health Office, Guernsey, Jan. 20th, 1912.

\section{THE FINSBURY MEDICAL SOCIETY AND TUBERCULOSIS DISPENSARIES.}

\section{To the Editor of THE LANCET.}

SIR, - At a meeting of the Finsbury Medical Society held on Friday, Jan. 19th, the following resolution was unanimously passed :-

That the Finsbury Medical Society presents strenuous opposition to the establishment of a tuberculosis dispensary in Finsbury on the lines proposed by the Central Committee for the Establishment of Tuberculosis Dispensaries.

I am, Sir, yours faithfully, W. Francis Roe, Hon. Sec.

Northampton-square, E.C., Jan. 20th, 1912. 